\title{
Effect of Plant Spacing on Onion (Allium cepa L.) Seeds Quality
}

\author{
Ayoub Zeyada Elhag", Hala Mohamed Osman \\ College of Agricultural Studies, Sudan University of Science and Technology, P.O.Box 71, Khartoum North, Sudan \\ *Corresponding Author: zadhag@yahoo.com
}

Copyright (C) 2013 Horizon Research Publishing All rights reserved.

\begin{abstract}
This study was conducted to evaluate the effect of plant spacing on onion seed quality, The experiments were executed at the nursery of Horticulture Administration, Ministry of Agriculture and Animal Resources and the labouratory of the Agricultural Research Station , Northern State, Sudan, in two successive seasons (2010 -2011and 2011-2012). In the nursery the bulbs of cultivar "Bafetaim (s)" were planted on both sides of $70 \mathrm{~cm}$ ridges at $2.5,5,10$ and $12.5 \mathrm{~cm}$ within ridge spacing. The cultural practices were followed as recommended till seed harvest. The experimental units were in completely randomized block design with four replications. After harvest the seeds were tested directly for germination (germination percentage, rate and uniformity) in petri dishes and emergence(emergence percentage, rate and uniformity) in soil in plastic seeds were again tested for germination after one and two years storage in paper bags at room temperature. All seed tests experiments were in completely randomized design with three replications. The results showed that the widest spacing had positive effects on germination and emergence percentage and rate. The closest spacing had positive effects on germination and emergence uniformity as well as ageing or deterioration rate. It could be concluded that closer plant spacing has no significant effect on onion seed quality moreover, it may reduce ageing rate during storage under normal storage conditions. However, the closest within row spacing $(2.5$ and $5 \mathrm{~cm})$ might be tedious and labourious compared to medium ones $(10 \mathrm{~cm})$. So medium within row spacing $(10 \mathrm{~cm})$ could be recommended for high onion seed yield (data not shown) and quality in the Northern State, Sudan and areas of similar environmental conditions.
\end{abstract}

Keywords Plant Spacing, Onion, Allium Cepa, Seed Quality, Seed Ageing

\section{Introduction}

Onion (Allium cepa L.) which belongs to the family Alliaceae is one of the most important vegetables. It contains some important vitamins (A, B and B2) and minerals (Ca, P, $\mathrm{Fe}, \mathrm{Cu}$ and $\mathrm{Zn}$ ) in addition to some soluble sugars and nicotinic acid. It is grown from either seeds, transplants or sets, for both green and dry bulbs [1]. The leading onion producer countries are China, India, USA and Turkey [2]. In Sudan onion is the most widely grown vegetable (between latitudes $3^{\circ}$ and $23^{\circ}$ North). With an average area of 84000 ha it constitutes about $33 \%$ of the total area under vegetable production (Fedral Ministry of Agriculture and Forestry, Khartoum, Sudan, 2008)

One of the major onion production problems is lack of high quality seeds and improper agronomic practices used by farmers. The main seed supply is from unreliable sources, where after number of market picks the late fruits or part of the crop is kept for seeds. Such seeds are usually of low quality (viability, vigor and genetic purity). However, they are kept for the next season and the surplus is sold to neighbour farmers [3]. Brewster [2] reported that optimum plant spacing and high quality seeds were considered important for optimum plant growth and high yield and quality. Plant and raw spacing are considered important to the optimum plant population which may be reflected in optimum yield and quality as shown by many researches. Levy et al. [4 ] found that under arid conditions large mother bulbs and high plant density $(60 \mathrm{~cm}$ inter-row and $10 \mathrm{~cm}$ intra-row spacing) gave the best results. Singh, et al. [5 ] studied six plant spacing $(30 \times 30,30 \times 45,30 \times 60,45 \times 45$, $45 \times 60$ and $60 \times 60 \mathrm{~cm}$. They found that the highest planting density $(30 \times 30 \mathrm{~cm})$ gave a significantly higher seed yield per unit area compared to other spacing but the lowest seed yields per umbel and per plant and 1000 seed weight. References [6-9,] reported no significant effects of plant spacing on onion seed quality. (1000 seed weight and germination percentage and rate), Similar results were also obtained by $[10,11]$ on grain legumes. References $[12,-, 14]$ reported that wider spacing had significant positive effects on 1000 seed weight but not the germination percentage of cotton and onion seeds, respectively. They recommended medium plant spacing for high seed yield and quality. References $[15,16]$ found no significant effect of bulb size and planting density on seed quality. 
Factors affecting seed quality before harvest may have further impact. For example they might increase seed deterioration rate during storage. In general, longer seed storage life is obtained if seeds are kept dry and at low temperatures $[17,18]$. Many vegetable seeds will maintain germination rates of at least $50 \%$ for ten or more years. However, the relative longevity of onion seeds under cool and dry conditions is $1-2$ years [17,19]. Seed germination and vigour are the main seed physiological quality attributes affected during seed deterioration.

This work was carried out to study how far the higher seed yields per unit area obtained at close within row spacing are also of high quality after harvest and storage.

\section{Materials and Methods}

This study was conducted in the nursery of Ministry of Agriculture and Animal Resources, Dongla, Northern State, Sudan, during two winter seasons(2010/2011 and $2011 / 2012$ ). The soil is clay loamy of $7.6 \mathrm{pH}$ and $2.5 \mathrm{dS} / \mathrm{m}$ electric conductivity (Ec.).The maximum and minimum temperature was $37^{\circ} \mathrm{C}$ and $18.8^{\circ} \mathrm{C}$, respectively. Seed bulbs of onion cultivar "Bafetaim" were obtained from Dongla Research Station, Northern State, Sudan. The bulbs of almost the same size $(45-50 \mathrm{~mm})$ were planted manually on both sides of $70 \mathrm{~cm}$ ridges at $2.5,5,10$ and $12.5 \mathrm{~cm}$ within row spacing, in December 2010 and November 2011. The experimental units were in completely randomized block design with four replications. They were irrigated at 7 days interval and the other cultural practices (fertilizer application, weeding and pest control) were done as recommended. Seed samples were drawn from seeds obtained at each within row spacing and tested for germination (germination percentage, rate and uniformity) on filter paper in petri dishes and for emergence (emergence percentage, rate and uniformity) in loamy soil in plastic bags, directly after harvest in each season and for germination ( germination percentage, rate and uniformity) after one and two years storage at the seed laboratory of Dongla Agricultural Research Station, Northern State, Sudan. They were stored in paper bags at room temperature. In both tests 50 seeds were used in each experimental unit and according to [20]. They were in completely randomized design with three replications. The data were analyzed using soft ware package MSTATC and the means were separated using LSD method at $p \leq 0.05$ [21].

\section{Results and Discussion:}

As in Table1, increasing of plant spacing increased 1000 seed weight, germination percentage and uniformity but delayed germination rate in both seasons, especially at the widest spacing $(12.5 \mathrm{~cm})$ compared to the narrowest one $(2.5 \mathrm{~cm})$. However, no significant effects were recorded. The same effect was noticed on seed emergence (Table2), where increased plant spacing increased emergence percentage and uniformity and decreased emergence rate in both seasons. However, no significant differences were noticed. Similarly $[12,-, 14]$ reported that wider spacing had significant positive effects on 1000 seed weight but not the germination percentage of cotton and onion seeds, respectively. They recommended medium plant spacing for high seed yield and quality.

Table1. Effect of plant spacing on seed quality (germination (G.) percentage, rate and uniformity) of onion. (Winter 2010/2011 and 2011/2012)

\begin{tabular}{|c|c|c|c|c|c|c|c|c|}
\hline \multirow{2}{*}{$\begin{array}{l}\text { Plant } \\
\text { spacing } \\
(\mathrm{cm})\end{array}$} & \multicolumn{4}{|c|}{ Season $2010-2011$} & \multicolumn{4}{|c|}{ Season $2011-2012$} \\
\hline & $\begin{array}{l}1000 \text { seed } \\
\text { weight }(\mathrm{g})\end{array}$ & G. $(\%)$ & $\begin{array}{l}\text { G .rate } \\
\text { (day) }\end{array}$ & $\begin{array}{l}\text { G. uniformity } \\
\text { (seeds/day) }\end{array}$ & $\begin{array}{l}1000 \text { seed } \\
\text { weight }(\mathrm{g})\end{array}$ & G. $(\%)$ & $\begin{array}{l}\text { G. rate } \\
\text { (day) }\end{array}$ & $\begin{array}{l}\text { G. uniformity } \\
\text { (seeds/day) }\end{array}$ \\
\hline 2.5 & $3.5 \mathrm{a}$ & $91.2 \mathrm{a}$ & $4.9 \mathrm{~b}$ & $8.1 \mathrm{c}$ & $3.5 \mathrm{c}$ & $92.0 \mathrm{~b}$ & $5,0 \mathrm{~b}$ & $8.6 \mathrm{~b}$ \\
\hline 5 & $3.6 \mathrm{a}$ & $93.5 \mathrm{a}$ & $5.7 \mathrm{ab}$ & $8.9 \mathrm{c}$ & $3.6 \mathrm{bc}$ & $97.3 \mathrm{a}$ & $5.5 \mathrm{ab}$ & $9.1 \mathrm{ab}$ \\
\hline 10 & $3.7 \mathrm{a}$ & $96.0 \mathrm{a}$ & $5.6 \mathrm{ab}$ & $9.3 \mathrm{ab}$ & $4.1 \mathrm{ab}$ & $98.0 \mathrm{a}$ & $6.0 \mathrm{ab}$ & $9.2 \mathrm{ab}$ \\
\hline 12.5 & $4.2 \mathrm{a}$ & $97.7 \mathrm{a}$ & $6.0 \mathrm{a}$ & $10.0 \mathrm{a}$ & $4.2 \mathrm{a}$ & $98.5 \mathrm{a}$ & $6.4 \mathrm{a}$ & $10.5 \mathrm{a}$ \\
\hline $\begin{array}{l}\text { LSD at } \\
\mathrm{p} \leq 0.05\end{array}$ & 1.2 & 6.3 & 1.0 & 0.9 & 0.6 & 2.6 & 1.1 & 1.5 \\
\hline
\end{tabular}

Means having similar letters were not significantly different using LSD at $\mathrm{p} \leq 0.05$.

Table2. Effect of plant Spacing on seed Quality (Emergence (E.) percentage, rate and uniformity) of onion.(Winter 2010/2011 and 2011/2012).

\begin{tabular}{ccccccc}
\hline Plant & \multicolumn{3}{c}{ Season $2010-2011$} & \multicolumn{3}{c}{ Season $2011-2012$} \\
\hline $\begin{array}{c}\text { spacing } \\
(\mathrm{cm})\end{array}$ & $\begin{array}{c}\text { E. percentage } \\
(\%)\end{array}$ & $\begin{array}{c}\text { E. rate } \\
(\text { days })\end{array}$ & $\begin{array}{c}\text { E. uniformity } \\
(\text { seed/day })\end{array}$ & $\begin{array}{c}\text { E. percentage } \\
(\%)\end{array}$ & $\begin{array}{c}\text { E. } \\
\text { rate } \\
\text { (days) }\end{array}$ & $\begin{array}{c}\text { E. } \\
\text { uniformity } \\
\text { (seed/day }\}\end{array}$ \\
\hline 2.5 & $91.3 \mathrm{a}$ & $7.4 \mathrm{a}$ & $7.2 \mathrm{~b}$ & $94.7 \mathrm{a}$ & $7.4 \mathrm{a}$ & $6.3 \mathrm{a}$ \\
5 & $93.5 \mathrm{a}$ & $7.1 \mathrm{a}$ & $7.47 \mathrm{~b}$ & $95.5 \mathrm{a}$ & $7.7 \mathrm{a}$ & $7.0 \mathrm{a}$ \\
10 & $96.0 \mathrm{a}$ & $9.2 \mathrm{a}$ & $8.0 \mathrm{ab}$ & $96.0 \mathrm{a}$ & $8.2 \mathrm{a}$ & $6.7 \mathrm{a}$ \\
12.5 & $97.8 \mathrm{a}$ & $8.2 \mathrm{a}$ & $8.7 \mathrm{a}$ & $98.2 \mathrm{a}$ & $8.3 \mathrm{a}$ & $6.9 \mathrm{a}$ \\
\hline $\begin{array}{c}\text { LSD } \\
\mathrm{p} \leq 0.05\end{array}$ & 6.3 & 2.2 & 1.2 & 4.0 & 1.3 & 0.7 \\
\hline
\end{tabular}

Means having similar letters were not significantly different using LSD at $\mathrm{p} \leq 0.05$. 
Table3. Effect of plant spacing on onion seed quality (germination (G.) percentage, rate and uniformity) after one and two years storage

\begin{tabular}{|c|c|c|c|c|c|c|}
\hline \multirow{2}{*}{$\begin{array}{l}\text { Plant } \\
\text { spacing } \\
(\mathrm{cm})\end{array}$} & \multicolumn{3}{|c|}{ After one year storage } & \multicolumn{3}{|c|}{ After two years storage } \\
\hline & $\begin{array}{c}\text { G. percentage } \\
(\%)\end{array}$ & $\begin{array}{c}\mathrm{G} . \\
\operatorname{rate}(\text { day })\end{array}$ & $\begin{array}{l}\text { G. uniformity } \\
\text { (seed/day) }\end{array}$ & $\begin{array}{c}\text { G. percentage } \\
(\%)\end{array}$ & $\begin{array}{c}\mathrm{G} . \\
\text { rate (day) }\end{array}$ & $\begin{array}{c}\text { G. } \\
\text { uniformity (seed/day) }\end{array}$ \\
\hline 2.5 & $83.5 \mathrm{a}$ & $3.5 \mathrm{a}$ & $3.7 \mathrm{a}$ & $74.0 \mathrm{a}$ & $3.4 \mathrm{a}$ & $3.4 \mathrm{a}$ \\
\hline 5.0 & $76.3 \mathrm{ab}$ & $3.9 \mathrm{a}$ & $3.7 \mathrm{a}$ & $67.5 \mathrm{ab}$ & $3.6 \mathrm{a}$ & $3.4 \mathrm{a}$ \\
\hline 10.0 & $74.4 \mathrm{~b}$ & $3.6 \mathrm{a}$ & $3.4 \mathrm{a}$ & $64.5 \mathrm{ab}$ & $3.7 \mathrm{a}$ & $3.2 \mathrm{a}$ \\
\hline 12,5 & $69.5 b$ & $3.5 \mathrm{a}$ & $3.6 \mathrm{a}$ & $58.6 \mathrm{~b}$ & $3.5 \mathrm{a}$ & $2.7 \mathrm{a}$ \\
\hline $\begin{array}{c}\mathrm{LSD} \\
\mathrm{p} \leq 0,05\end{array}$ & 7.5 & 0.6 & 0.6 & 12.7 & 0.6 & 0.9 \\
\hline
\end{tabular}

Means having similar letters were not significantly different using LSD at $\mathrm{p} \leq 0.05$

After one or two year storage no significant differences (Table3) among the different plant spacing were noticed on seed quality (germination percentage, rate and uniformity). However, seeds produced at the closet spacing $(2.5 \mathrm{~cm})$ were less affected by storage compared to those obtained at the widest spacing $(12.5 \mathrm{~cm})$. It was clear that increased seed weight at wider plant spacing due to low competition for nutrients between plants as stated by many researchers $[6,7,9]$ had no significant effect on onion seed quality. However, it has positive effects on seed germination percentage and uniformity but reduced germination rate, which could be attributed to the abundant food reserve ( low within row competition) and moisture for active growth of the embryo on the short run (directly after harvest or short storage period) as stated by [1314]. On the long run (long storage period) the reverse would take place due to high moisture and high temperature resulted from excessive biological processes e.g. respiration. Seeds retain their quality for longer periods if they are stored at relatively low moisture content and low relative humidity $([17,19]$. At high storage temperatures and high relative humidity in addition to high food reserve (high seed weight) onion seeds lose viability quicker than many vegetable seeds and this can be a serious problem in local seed production in tropical areas [22].

Similar results were also obtained by $[10,11$,$] on grain$ legumes and $[23,8])$ on onion.

It could be concluded that closer plant spacing has no significant effect on onion seed quality moreover, it may reduce ageing rate during storage under normal storage conditions. However the closest within row spacing (2.5 and $5 \mathrm{~cm})$ may be tedious and labour consuming compared to medium one $(10 \mathrm{~cm})$. So medium within row spacing $(10 \mathrm{~cm})$ could be recommended for high yield and quality onion seeds in the Northern State, Sudan and areas of similar environmental conditions.

\section{REFERENCES}

[1] D. R. Decoteau. Vegetable Crops, ed. Prentice- Hall, Inc. New Jersy, USA, 2000.

[2] J. L. Brewster. Onion and other vegetable alliums. Cab International, Wallingford, UK, 1994.

[3] A. E. Ahmed. The effect of seed maturity, moisture content and storage period on seed germination and dormancy of okra (Abelmoschus esculentus L.). M.Sc., Thesis, Faculty of Agriculture. University of Khartoum, Sudan, 1994.

[4] D. Levy, B.Z. Herut, N. Albasel, N. Kaisi and I. Manasra. Growing onion seeds in an arid region: drought tolerance and the effect of bulb weight, spacing and fertilization. Journal of Horticultural Science. Vol.14, No.1, 1-7, 1981.

[5] D. Singh, H. Singh, S. S. Gill and M. L. Chadha. Effect of plant density on onion seed yield. Annals of Biology (Ludhiana), Vol. 6, No. 2, 171-172, 1990

[6] S.K. Sharma and G. LAL. Effect of plant spacing on radish seed yield and quality. Vegetable Science. Vol. 18, 82-87, 1991

[7] S.R. Singh and B.P. Sachan. Interaction of bulb size and spacing on seed yield and yield attributing traits of onion (Allium cepa L.) cv.Kalyanpur Runel Red. Scientific Horticulture. Vol. 6, 18-25, 1999

[8] R. Aminpour, A. Mortazavibak and A. A. Jafari. Effect of planting date and within row spacing on seed quantity and quality of onion (Allium cepa L.) cv. Yellow Sweet Spanishs. Irranian Journal of Horticultural Science and Technology. Vol. 6, No .4, 183-190, 2006

[9] M. Khodadadi. Effect of mother bulb size, plant density and planting date on the yield and the yield components of onion variety Abhar. Islamic Azad Publication. Iran, 2009.

[10] M. A. Nadeem,, , A. Ali, S Rashid,. and, M. Magbool. Effect of different planting pattern on growth, yield and quality of grain legumes. Pakistan Journal of Life Society Science, Vol. 2, No.2, 132-135, 2004

[11] V.K. Shah. Effect of sowing time and row spacing on yield and quality of pea crop at Rampur Chitwan, M.Sc. Thesis, IAAS, Chitwan, Nepal, 2005.

[12] H. Awan, I. Awan, M. Mansoor, E.A. Khan, and M. A. Khan. Effect of sowing time and plant spacing on fiber and cotton seed yield and quality. Sarhad Journal of Agriculture. Vol. 
27, No.3, . 411-413, 2011

[13] M.D. Asduzzaman, M. D. Hasan, M .D. Hasan and M. D. Moniruzzaman. Effect of bulb size and plant spacing on seed production of onion (Allium cepa L.). Bangladesh Journal of Agriculture Research. Vol. 37 No. 3, 405-414, 2012

[14] Z. Zena.The effect of bulb size and plant density on yield and quality of onion (Allium cepa L.) seeds at Ziway, Central Ethiopia. On line available from www. Google .com/ books, August 2013

[15] S. Gamiely, D. A. Smittle, H.A. Mills and G.I. Banne. Onion seed size, weight and element content affect germination and bulb yield. Horticultural Science. Vol. 25, 522-523, 1990

[16] M. Morozowska and R Hołubowicz. Effect of bulb size on selected morphological characteristics of seed stalks, seed yield and quality of onion (Allium cepa L.) seeds. Journal of Agricultural Research. Vol. 21, No. 1, 27-38, 2009

[17] P.K. Agrawal Seed storage and packaging, In Quality Seed Production, A. J. Van Gastel and J. Kerley, International Center for Agricultural Research in the Dry Areas , Syria, 1986
[18] R.J. Probert and F.R. Hay. Keeping seeds a live, In Seed Technology and its Biological Basis (eds. M. Black and J.D.Bewley), Sheffield Acadamic Press, England, 2000

[19] C.L Stumpf,. S. T. Peske and, L. Baudet. Storage potential of onion seeds hermetically packaged at low moisture content. Seed Science and Technology. Vol. 25, N0. 1, 25-23, 1997

[20] ISTA. International Rules for Seed Testing. Seed Science and Technology. Vol. 27, (Supplement), 1999

[21] K. A. Gomez and A. A. Gomez. Statistical Procedures for Agricultural Research. John Wiley and Sons, New York., 1984

[22] M. Black, J. D. Bewley and P. Halmer. he Encyclopedia of Seeds Science, Technology and Uses (ed. Cromwell Press, Trowbridge), 2006

[23] Z. Barakauskienzi, R. Dris and O.I. Oladele. Effect of plant spacing and seed rate on onion quality and seed yield. Nigerian Journal of Horticultural Sciences. Vol. 7, No. 1, 22-25, 2002 